\title{
The Development of Accounting in UK Universities: An Oral History
}

Lorna Stevenson ${ }^{\text {a }}$, David Power ${ }^{b}$, John Ferguson ${ }^{*} \&$ David Collison ${ }^{d}$,

${ }^{a}$ Reader in Accounting, School of Management, University of St Andrews, Scotland, UK. E-mail: las27@st-andrews.ac.uk

${ }^{b}$ Professor of Business Finance, School of Business, University of Dundee, Scotland, DD1 4HN, UK. E-mail: d.m.power@dundee.ac.uk

$\mathrm{c}^{*}$ Corresponding Author: Professor of Accounting, School of Management, University of St Andrews, Scotland, UK. E-mail: jf60@st-andrews.ac.uk

${ }^{d}$ Professor of Accounting and Society, School of Business, University of Dundee, Dundee, DD1 4HN, Scotland. E-mail: d.j.collison@dundee.ac.uk 


\title{
The development of accounting in UK universities: An oral
} history

\begin{abstract}
This paper reports on the development of the accounting discipline in universities in England and Scotland from the 1960s. Drawing on the oral history narratives of six distinguished accounting scholars who played a significant role in the discipline, the paper documents: (i) the initial influences on the teaching of accounting in English universities; (ii) the different influences on the teaching of accounting in Scottish universities; and (iii) the influence of United States (US) universities and their scholars on the development of academic accounting in the UK. With a focus on the second wave of accounting professoriate who followed the London School of Economics (LSE) 'Triumvirate' of William Baxter, Harold Edey, and David Solomons, this paper provides first-hand insights into the shape and spread of university accounting education at a crucial stage of its development (Napier, 2011: 185). This, in turn, develops an understanding of the contemporary academic accounting discipline in the UK (van Wyhe, 2007).
\end{abstract}

\section{Keywords}


University accounting education, oral history, LSE Triumvirate

\section{Introduction}

The presence of accounting as an academic discipline in universities in the $\mathrm{UK}^{1}$ is relatively recent, largely emerging since World War II (Zeff, 1997). One consequence of this 'newness' is that it is possible to speak to the individuals who were active in shaping the developing and evolving academic discipline. Professor William Baxter was appointed to the first full-time accounting Chair in the UK at the London School of Economics (LSE) in 1947. Widely acknowledged as influential in the development of academic accounting across the UK, his recollections of that time have been documented by accounting historians (Mumford, 2007; Walker, 2005)². Under his leadership at the LSE, a dedicated Master's degree programme was launched, the graduates of which often went on to lecturing and professorial appointments in the 1960s and 1970s. These individuals were closely involved in developing the academic discipline of accounting more widely in the UK and, following the initial chair appointments in the 1940s, they represent the second wave of accounting professors in the UK. The third wave commenced with the appointment of the first woman to an accounting chair in the UK, Susan Dev, who gained this promotion in 1980 at the LSE (see also Parker, 1978). 
Perks (2004) describes the emergence of British accounting academia in an introductory section of his financial accounting textbook:

'Accounting has mostly been a practical subject rather than a theoretical one, but it does have some respectable academic roots. In Scottish universities it tended to develop in law faculties, and the subject may have been seen differently from England. Perhaps the practice of accountancy was primarily the application of legal concepts. In English universities the subject has developed more within an economics framework, with a London School of Economics' view rapidly spreading and predominating.' (Perks, 2004: 64).

While somewhat incongruous for an introductory textbook, these brief observations by Perks (2004) capture some of the central concerns of this paper and shape its three contributions. First, in presenting an oral history of key second wave accounting professors during the 1960s, this paper documents the different origins and subsequent influences on accounting as a developing academic discipline in England and in Scotland. We draw on the thoughts and recollections of six academics appointed to their first full-time posts teaching accounting at universities in England and Scotland from the mid-1960s. Although relatively small in number (e.g. see Mumford, 2007; Parker, 1994; Walker, 2005), the participants in this study offer valuable insights on the issues 
being examined. They remained in academia throughout their careers and began to retire from the 1990s. Thus, these individuals were present at the time when the accounting discipline started to increase in prominence (Dev, 1980; Geddes, 1995) as a distinctive subject area within a growing number of UK universities. Further, because of their relatively long careers, they helped to shape the discipline and influenced the direction of university-level accounting education.

Second, we provide first-hand insight into what Perks (2004) refers to as the 'rapidly spreading and predominating' LSE view through the voices of key members of this second wave of accounting professoriate. The first full-time UK accounting professors - the 'LSE Triumvirate' of William Baxter, Harold Edey and David Solomons-were appointed to their senior academic positions at the LSE from the 1940s (Napier, 2011: 185). The LSE view of accounting, discussed in more detail in the literature review below, can be characterised as an understanding of accounting that drew on economics (Walker, 2005). From the 1960s, candidates for professorships in accounting had often studied under the LSE Triumvirate or found themselves facing one of these individuals on chair selection panels.

Third, we reveal the influence of US academic developments on the teaching of accounting at UK higher education institutions. In particular, this paper highlights our particpants' views of the effect of research from the US on accounting teaching in the UK, and specifically, work underpinned by the agency theory assumptions promulgated 
by Jensen and Meckling (1976). The result, according to this second wave of accounting professors, was the rise to prominence of the view that the primary goal of business should be the maximisation of shareholder wealth (MSW). This view then spread to the curricula delivered in UK universities.

The remainder of this paper is structured as follows. After an overview of the relevant literature informing the study, we outline the method used when conducting this research; specifically, an oral-history approach is discussed and the backgrounds of the participants outlined ${ }^{3}$. The next section of the paper reports the findings from the participants' narratives. These findings are grouped into three broad themes: (i) the prominent role played by the LSE in shaping the teaching of accounting at English universities; (ii) differences in the development of university accounting education in Scotland compared with England; and (iii) the influence of US academics and their universities on accounting education in UK universities. Finally, some conclusions and suggestions for further work are offered in the closing section.

\section{Literature review}

The 1960s was a period during which the numbers of higher education institutions in Britain offering dedicated accounting programmes increased, the numbers of students on such programmes grew, and the accounting profession moved towards the graduate entry. We were interested to explore the background and aspirations of key individuals 
involved in shaping accounting education during this period ${ }^{4}$. We sought to understand the influences on what they taught in their classrooms, and the sources of any materials used. In this respect, a review of the prior literature examining the emergence of accounting as a university discipline highlights a number of themes relevant to our findings.

First, there were distinct differences between Scotland and England in terms of the presence of, and influences on, accounting in universities. From the beginning of the twentieth-century ${ }^{5}$ accounting courses in UK universities tended to be located in commerce degrees. Degree programmes dedicated to accounting only began to appear in British universities during the late 1960s, prompted in part by the government's expansionary plans for higher education under the Robbins Report (Parker, 1997: 47; see also Annisette and Kirkham, 2007; Evans, 2009; Poullaos, 2010) ${ }^{6}$. This growth is reflected in statistics from that period: although accounting could be studied at twelve English universities in 1961, only three of these institutions offered the subject as part of a named study programme (Geddes, 1995: 201). Strikingly, by 1978 the numbers had more than doubled, to twenty-eight and twenty-two respectively (Geddes, 1995: 217). Dev (1980: 8) draws on other statistics to illustrate this expansion in the teaching of accounting at universities, noting that 'in 1968 there were only six full-time professors of accounting in Britain' compared with forty-three in $1980^{7}$. Significantly, of the twenty-one accounting chairs at UK universities in 1971, 'all but one of the incumbents 
held a professional qualification, but only three held higher degrees and only one of these was a PhD' (King and Davidson, 2009: 264).

Even so, Geddes (1995: 38) notes 'an anti-vocational university system’ in England, which was characterised by unwillingness on the part of both universities and professions to work closely together. By contrast, these two groups collaborated in the delivery of accounting education in Scotland. From its inception in the nineteenth century, (at least one of the predecessor bodies of) the Institute of Chartered Accountants of Scotland (ICAS) has typically required their aspiring members to have some university instruction in law, economics and accounting. The effects of these initial differences appeared to persist up to the time when our participants started working in higher education.

Second, prior work in this area (Badua et al., 2011; Heck and Jensen, 2007; Rodgers and Williams, 1996; Zeff, 1997) notes that the establishment of the first accounting journals had an impact on both the dissemination of ideas among accounting academics, and on the research that was undertaken as part of the discipline's development. Key here is the earlier emergence of academic accounting in the US, and the specific roles of the LSE (especially Baxter) and the economics discipline more generally.

\section{Accounting education in Scotland and England}


While a university degree in accounting was not always required, mandatory university education in law for accounting apprentices in Scotland dates to 1866 (Walker, 1988). From 1926 this legal training was supplemented by compulsory classes in economics and accounting (Shackleton, 1992 see also Napier, 1996a). Having trained in Scotland, Baxter recalled that:

'[...] in the post war period [the Scottish Institute] introduced a system whereby all articled clerks had to go and have a year off from their office to take three courses at a university' (Walker, 2005: 33).

Even if close links existed between the professions and the universities in much of the western world, the situation in England was very different (Annisette and Kirkham, 2007; Baxter, 1988; Evans, 2009, 2010, 2014; Gammie and Kirkham, 2008). As recently as the 1970s the Institute of Chartered Accountants in England and Wales (ICAEW) had 'not developed its training, education or certification within the university sector' (Annisette and Kirkham, 2007: 1). Although ICAEW did employ a large number of graduates after the 1960s expansion of higher education in the UK, these were rarely holders of degrees in accounting (Annisette and Kirkham, 2007; Parker, 1978). A member of the first wave of accounting professors, David Solomons (1961), attributed to the ICAEW an 'attitude of indifference to university studies in 
accounting' (King and Davidson, 2009: 264; see also Annisette and Kirkham, 2007; Dev, 1980; Gammie and Kirkham, 2007). Baxter himself recalled the 'very hostile and philistine' attitude of the English Institute to universities, which he starkly juxtaposed with his experience of the Scottish Institute, and of two other English professional accounting bodies, during his time at the LSE (Walker, 2005: 33).

\section{The influence of economics on research in accounting in British universities}

Even though the influences on university education in Scotland and England varied, the academic literature provides more uniform views about the character and significance of the accounting research undertaken in universities across the UK up to the 1970s. Within England during 1947, full-time professors in accounting were firstly appointed in economics departments (Napier, 1996a) with William Baxter getting a Chair at the LSE and Donald Cousins at the University of Birmingham. Geddes (1995) reports scant signs of any 'formal' accounting research before 1945 in UK universities ${ }^{8}$. In 1954, Stacey (1954: 245, cited in Annisette and Kirkham, 2007: 16) declared that the accomplishments of academic accounting were 'dismal'. Even by 1975, Tricker (1975: 21, cited in Geddes, 1995: 45) observed that 'there has been no serious academic [accounting] research tradition in [the UK]'. Nonetheless, the first research committee of a professional accounting institute in the UK had been formed in 1935 (Zeff, 1997: 6), which in turn launched the journal Accounting Research in 1948 to 'provide for 
accountancy a periodical of the standing of The Economics Journal in economics' (Zeff, 1997: 14). The influence of economics on the emerging academic discipline of accounting is also clear in Baxter's recollection of the genesis of the Association of University Teachers of Accounting (AUTA), which today is known as the British Accounting and Finance Association (BAFA). Baxter (from Walker, 2005: 33) recalls that he:

'[...] had noticed that there was a vigorous body called the Association of University Teachers of Economics and it struck [him] that we might have a similar one linking up all the teachers of accounting at the different universities’.

The timing of the AUTA meetings was subsequently arranged so as not to clash with similar conferences in economics. This was to enable academic economists to provide conference papers or attend as delegates (Parker, 1997; Zeff, 1997). The notable role of the LSE and specifically Baxter, in shaping the teaching of accounting in UK universities is an issue addressed in some detail by Napier (1996a, 1996b, 2011); his key relevant insights are now presented.

\section{The London School of Economics}


The influence of the LSE on academic accounting through the activities of its staff, especially Baxter, has been profound. In 1964, under Baxter's leadership, the LSE introduced a taught Master's degree in Accounting and Finance which drew broadly from the social sciences, and especially economics (Dev, 1980; Walker, 2005). This education programme proved popular with accountants lacking a first degree, who sought knowledge of the more academic aspects of accounting, which their practical experience had not developed (Dev, 1980: 10; see also LSE, 2007). The consequential impact of the LSE emerges when we consider that in 1980, of the 43 UK professors of accounting, 'twenty-three [...] [had] been at the LSE as students, teachers or research fellows.' (Dev, 1980: 8; see also Napier, 1996a, 1996b).

Even though he was appointed as a Professor of Accounting at the LSE, since entering academia, Baxter drew from the field of economics for insight into accounting. For example, he enthused about the strong influence throughout his academic work, of a close childhood friend, Harold Barger, subsequently a Professor of Economics at Columbia University. (Walker, 2005: 11). In addition, he also noted the significant continuing impact on his thinking of the renowned economists Kenneth Boulding - with whom he worked at the University of Edinburgh in the 1930s - and Frank Paish - an academic at the LSE between 1932 and 1965 (Mumford, 2007: 42).

Also notable in the context of our own findings, Baxter speculated that the impact of lawyers on the accounting discipline would have been before his time and that their 
influence had waned significantly by the 1970s (Mumford, 2007). However, in Scotland, Walker (2005: 57) highlights that the University of Glasgow’s accounting education developed through the joint efforts of the Departments of Economics and Law.

The rich detail of Walker's (2005) and Mumford's (2007) oral histories involving key figures in the accounting profession-amongst these, members of the first wave of accounting professors-highlights two issues of note. These are the crucial impact of the LSE's economics approach to the university teaching of accounting in the UK, and the influence of the accounting profession on the emerging academic accounting discipline.

\section{Academic accounting in the US}

Van Wyhe locates the beginning of academic accounting education in the United States to the 1880s, and he notes that the perennial debate between theory and practice dates from that time (2007: 166). University level accounting in the early twentieth century in the US was ahead of its UK counterpart; specifically, he noted that 'by the mid-1920s, three hundred and thirty-five schools of higher education [in the USA] taught accounting; at least sixty of these schools offered a Bachelor of Arts (BA) in Accounting, while thirty schools offered a Master's degree in Accounting' (van Wyhe, 2007: 167). This period also saw other milestones in the development of academic 
accounting in the US: the launch of that nation's first academic accounting journal, The Accounting Review in 1926, the creation of the first association of accounting academics in 1916, and a subsequent proliferation of accounting textbooks for use throughout the accounting world (Napier, 1996a; Zeff 1997).

It is perhaps unsurprising that Baxter travelled to the US, wishing to study the academic discipline of accounting. In the early 1930s, his professional practice employer provided him with an opportunity to become involved in teaching at the University of Edinburgh. Through this employer, Baxter became aware of, applied for, and won, a Commonwealth Fund scholarship for a two-year visit, first at the University of Pennsylvania's Wharton Business School and then at Harvard. Baxter's own fulltime lecturing career then began on his return to Scotland in 1934. Subsequently, he 'established a relationship with the University of Chicago which led to the foundation of the Journal of Accounting Research as a joint venture of Chicago and the LSE' (Walker, 2005: 5).

Despite his experiences, Baxter later could think of no influences from the US on accounting ideas in the UK (Mumford, 2007: 17). However, in a detailed account of the LSE, Napier (1996a: 470-473) notes the influence of Northern American writers and researchers; further he locates the influence on British academics of theoretical economics from the US from around 1965. This view about the influence of US economics-based scholarship on the teaching of academic accounting is reinforced by 
an analysis of information from one of the key US journals in the discipline: The Accounting Review.

Based on a content analysis between 1926 and 2005, Heck and Jensen (2007: 109) conclude that 'a sweeping change in editorial policy occurred in the 1960s and 1970s that narrowly defined scholarly research in accounting as that which employs accountics'. The term 'accountics' is defined by the authors as 'scholarly accounting research [which] is overly focused on mathematical analysis and empirical research' (Heck and Jensen, 2007: 109). The authors further note that between 1986 and 2005, 99\% of all articles in The Accounting Review were of a very specific type of research and they, '[...] contained mathematical equations and multivariate statistical analyses [...] amenable to analysis using mathematics, management science, econometrics and psychometrics’ (Heck and Jensen, 2007: 111; see also Badua, Previts, and Vasarhelyi, 2011; Rodgers and Williams, 1996).

Similarly, Reiter and Williams (2002: 576) note that 'there was a revolutionary change in accounting research in the 1960s and 1970s [...] to an empirical economic-based research program'. They conclude from their citation and authorship analysis that, '[accounting’s] academic élite had constructed academic accounting research as a 'partition' of economics' (Reiter and Williams, 2002: 590) such that it resulted in an 'economic domination of the academy' (Reiter and Williams, 2002: 583). Assessing the potential impact on accounting teaching of this domination by economics, Lee (1995: 
252) notes that 'publications in what are perceived to be élite journals [enhanced] the ability of the researcher to progress in a career as an educator' (see also Long et al., 1998).

What emerges from an analysis of the literature is a number of themes about influences on accounting as an academic discipline at UK universities. These themes-distinctive differences between Scotland and England, the impact of the LSE, and of US scholarship_-are explored with a small group of second wave accounting professors who worked in UK universities from the late 1960s and early 1970s until their retirements. As such, the oral histories of these individuals build upon previous analyses that have been conducted, and extend the time periods that have been considered in past studies (Mumford, 1991, 2007; Parker, 1994; Parker et al., 2012; Walker, 2005).

\section{Method}

This paper reports on the oral history narratives of six accounting academics, who played a significant role in the development of accounting as a higher education discipline in the UK from the 1960s. Sian (2006: 296) notes that the oral history approach 'attempts to capture the personal experiences and views of key actors who were party to the processes.' The method, therefore, provides the researcher with the ability to 'question the makers of history face to face' (Perks, 1995, as cited in Sian, 2006: 299). There is a sizeable, though not dominant, body of historical research in 
accounting that is informed by the oral history tradition (for example, see: Baskerville, 1999; Burrows, 1999; Collins and Bloom, 1991; Fleischman and Radcliffe, 2005; Hammond and Sikka, 1996; Haynes, 2010; Matthews, 2000; Mumford, 1991; Parker, 1994; Spacek, 1990; Walker, 2005).

Much of the oral history research in accounting has been influenced by Hammond and Sikka’s (1996: 79) call for 'radicalizing accounting history' and the need to give voice to the 'lived experiences of ordinary people who are affected by accounting and shape its development.' Addressing this call, a number of studies have explored oral history accounts in order to critically examine the role of accounting or of its profession in relation to race (Hammond, 2002), gender (Haynes, 2008a, 2008b), the intersection of race and gender (Fearfull and Kamenou, 2006; Kyriacou, 2000; McNicholas et al., 2004) and disability (Duff and Ferguson, 2011a, 2011b). Nevertheless, not all oral history work in accounting is primarily concerned with issues of social inequality or providing a voice to suppressed groups. For example, the oral history approach has been employed to provide historical accounts of 'major figures in the field' of accounting (Hammond and Sikka, 1996: 81). Notable examples of such work include Spacek’s (1990) account of Arthur Andersen \& Co. (1928-1973), Mumford's (1991) history of prominent twentieth-century accountants and Parker's (1994) examination of the life and career of the leading Australian accounting scholar, Louis Goldberg. The study presented here continues in this vein. 
The oral history approach 'encapsulates various forms of in-depth life history interviews, biographical interviews, and personal narratives’ (Haynes, 2008b: 628). This approach differs from traditional interviews, which tend to be more structured in terms of the interviewee providing answers to a list of questions (Parker, 1997). Oral history takes a more unstructured approach, allowing narrators to express their voice and reflect upon their experience. However, as Walker (2005: iii) notes:

'No-one should be under any illusions that gathering oral testimony is a 'soft' form of historical research. Oral history properly conducted involves substantially more than recording a genial conversation over afternoon tea ... [Conducting oral history interviews involves] preparatory research on the interviewee, composing informed questions, organising interviews, mastering recording technology, building rapport with the subject, and the need to combine sensitivity and authority to keep the interview on track.'

These challenges are also delineated by Parker (1997: 141), who emphasises the importance of consulting the background literature prior to gathering testimony and for the interviewer to become familiar with the relevant 'context, issues [and] terminology' (see also, Collins and Bloom, 1991).

While traditional interviews are often restricted to specific events, oral histories 'deal 
more broadly with a person's past, and range widely over a number of topics' and are, therefore, more appropriate as a means of providing insight into people's lives and life experiences (Reinharz, 1992: 130; see also Collins and Bloom, 1991; Haynes, 2008a). In this sense, oral history allows us to locate experiences in their contexts, to understand the significance of their antecedents and appreciate their emergence through time (Yow, 2005: 13). In seeking to understand influences on accounting education, we note the significance of the testimony of direct participants in those events (Perks and Thompson, 1998: ix). Further, Walker (2005: iii) notes the importance of documenting the experiences of those involved during 'a period of momentous change in [...] accounting education.’

While oral history may provide for a more personal and immediate form of history, compared to traditional textual sources, the approach carries a number of limitations (Parker, 1997). For example, as Burrows (1999: 100) explains:

‘Oral history involves appropriating other peoples’ experiences and memories for authors' historical purposes. Inevitably, authors will see these experiences differently than informants, and select, emphasise and contextualize material in ways which may not accord to informants’ perceptions.'

Similarly, Parker (1997: 142) observes that, '[...] recollections may be contaminated by 
information [...] absorbed from other sources, nostalgia for times past or some sense of past grievance.' Further, the participant may simply 'not be willing to tell the truth about certain events’ (Parker, 1997: 142). For these reasons, Collins and Bloom (1991: 29) recommend that oral history should be used in conjunction, insofar as it is possible, with other documentary evidence. Our research, therefore, draws on the literature in shaping the approach, the questions asked and any further discussion. In addition, we use prior work to anchor and contextualise our findings.

\section{Approach and participant recruitment}

Our oral history research was conducted with six professors in the field of accountancy and/or finance who had retired from their university posts during the 1990s. The participants were selected on the basis of the length of their experience as academics over at least three decades in UK universities, with the BAFA's) ${ }^{9}$ Distinguished Academic and Lifetime Achievement Awards used as a guide in the selection process ${ }^{10}$ (though not exclusively). Access and availability were also factors in the decision to approach an individual (see Table 1). Thus, the group of participants is not randomly selected and it is relatively small ${ }^{11}$. Nevertheless, it was felt that the recollections of those involved would offer unique insights about the history of accounting education at a time when universities in the UK were expanding their offerings in the subject and 
beginning to introduce dedicated degree programmes in the accounting area (Napier, 2011; Walker, 2005). ${ }^{12}$

\section{Insert table 1 about here}

An analysis of Table 1 indicates that all of the participants were male, and had gained a professional accounting qualification before entering academia. As indicated above, the first female accounting professor in the UK was appointed in 1980, and so the single gender of our participants was not unexpected (Parker, 1978). Half of them spent most of their working lives lecturing at Scottish universities while the others were mainly employed by institutions in England. In addition, three were awarded degrees from the LSE while the others achieved their academic qualifications elsewhere ${ }^{13}$. The groundbreaking work of the LSE in offering accounting degrees made it one of the few available places to study when these professors were students; it is perhaps unsurprising that half of our participants are its alumni. Despite the small number of participants, there is some variability in their backgrounds; thus, their insights may offer a range of views about the development of, and influences on, accounting as an academic discipline in the UK. 
Adopting an oral history approach (Hammond and Sikka, 1996), the researchers sought views about the development of accounting education in universities in the UK throughout the late 1960s and early 1970s. As noted above, the oral history approach is less structured than other interview-based approaches and so participants were asked to reflect upon three broad themes. The first theme concerned aspects of the participants' backgrounds, such as their own education, their professional qualifications and their decisions to enter academia. The second theme concerned participants' views about influences on the development of accounting at UK universities when those individuals were beginning their academic careers. Finally, the third theme concerned participants’ views of the role played by US academic writings and journals in informing the ideas that they taught about and researched. These themes were provided to participants before each meeting to indicate areas of interest for the discussion. However, as part of the approach employed, participants did not stick rigidly to the order of the themes as listed, nor did the researchers seek to constrain the direction or content of any discussions that took place.

We acknowledge, of course, that the oral history method is subject to a number of limitations (Parker, 1994), relying as it does on participants’ memories, perceptions and interpretations ${ }^{14}$. Nevertheless, it was felt that the insights to be gained from the participants outweighed any difficulties associated with the recollection of events and 
ideas from up to forty years beforehand. In addition, we were able to compare key recollections amongst the participants and with the extant literature.

Each conversation lasted an average of 90 minutes and was attended by at least two members of the research team. The conversations were recorded, transcribed and then analysed by all four members of the research team. Responses to each theme were documented and insights noted. Quotes were identified to illustrate the points being made. These points were summarised across all participants and the main findings highlighted.

\section{Findings from the oral histories}

The findings from the oral histories are summarised in three sections. First, we report on the views expressed by the participants about the influences on the teaching of accounting at English universities. We have alphabetically coded the participants. Second, we document the perceptions of the participants about influences on the teaching of accounting at Scottish universities - notably, on how the influences on those in Scotland differed from the influences on their English counterparts. The opinions of participants $\mathrm{D}$ and $\mathrm{F}$ are especially important in this section since they started their academic careers at Scottish universities; however, the thoughts of participants A, B and $\mathrm{C}$ also feature prominently in this section since they spent a sizeable period of time working in Scottish universities during the late 1960s or early 1970s. The final section 
focuses on the role played by US academics on the teaching of accounting at both English and Scottish universities through their writings, their visits and their editorship of, and reviews for, academic accounting journals.

\section{Influences on the teaching of accounting at English universities}

All of the participants in this study noted the prominent role played by the LSE in the development of accounting education at English universities ${ }^{15}$. In this regard, the opinions expressed by our respondents confirmed the earlier findings of Walker (2005) who provided an oral history of four of the 'most influential figures in the Scottish [accounting] profession.' Reflecting on the influence of the LSE within the context of academic accounting in the UK, Walker (2005: 37) cites the views of one of those four, Baxter, who noted:

'[...] when the general increase of the teaching of accounting took place, [the LSE had] a supply of recruits for all the chairs in Britain, and sure enough, men like Solomons and Carsberg, and John Flower and later Whittington went out and they peopled the chairs [...] with LSE graduates. This I suspect caused a certain amount of resentment, and there were mutters about the 'LSE Mafia' [emphasis added]'. 
The views expressed by our participants—-some of whom included members of the socalled 'LSE Mafia' who 'peopled the chairs', in accounting-also supported Napier's (2011: 197) observation that academic accounting across the UK was dominated by the LSE for a crucial period (see also Parker, 1995).

The two participants who had been awarded a degree from the LSE strongly held this view about the 'Mafia-like' control of one institution over the teaching of accounting across the UK They highlighted how the LSE was one of the first institutions in the UK to offer a commerce degree and appoint full-time professors ${ }^{16}$ in accounting. As participant B noted:

'The LSE triumvirate—Will Baxter, David Solomons and Harold Edey—were the foundation, intellectually, of post-war British accounting education [...] The LSE was very strong at that time; [in fact] it was dominant.'

Participant C attributed the LSE's prominent role in the development of accounting education within universities to the theoretical background that underpinned the teaching of the subject at the LSE:

'In the early to late 1960s [...] the teaching of accounting-even on the degree course that we had—was very much practice orientated. The teaching 
had very little theoretical content. It was still very much from books, which were emphasising the practical aspects [of the subject] [...] university staffheaded by the LSE—-started to be concerned with the theoretical [aspects of the subject]. If you looked at the LSE programmes at that time, they would have put quite a lot of emphasis on Hicks and the Hicksian concept of income as an increase in wealth. In a way, it was [...] a natural thing to seek a theoretical rationalisation [for accounting] by reference to economics ... The LSE was a School of Economics, Hicks was a very reputable economist and his work provided a fairly obvious possible rationale for accounting.'

He continued:

'[...] with the development of many accounting degrees across the country, there was a perceived need for the identification of a theoretical foundation for the discipline and because of the affinity of the LSE [...] there was a move towards economics.'

As discussed above, Baxter had noted the influence of economics during his own early academic life. He clearly stated, 'we had ideas derived from economists' (Walker, 2005: 32). 
Even those who had studied elsewhere recognised the LSE's prominent, and often controlling, role in the development of accounting education at English universities. For example, participant D argued that the LSE was able to dominate the development of the accounting discipline because it had been the first UK institution (sic) to appoint full-time professors in the subject. He added that:

'[...] they were generating lots of students of good quality and [...] almost had a mafia-like operation; they [placed their] students at other institutions. If you look at the history of [most other universities], the early professors [of accounting] all had LSE degrees.'

He continued:

'[...] whenever you went for a chair in accounting at that time [...] the external assessors were usually Baxter or Edey and then later, their protégés; it was a completely LSE-dominated [process].'

Participant A concurred with this perspective. He noted that: 
'Professor Harold Edey [from the LSE] was the person who turned up when you applied for a job; he was [usually] one of the external assessors.'

In A's opinion:

'[...] you really had to get on with Harold; now, to give him his due, the people that he supported were good people - but they were his people ${ }^{\text {, }}$.

In addition to their influence as external assessors for chair appointments at UK universities, two of the participants highlighted the role played by LSE staff in the development of accounting curricula at English universities. For instance, participant C pointed out that:

'[because the LSE's] graduates were providing many of the external examiners [for accounting programmes] and giving advice to polytechnics ${ }^{18}[\ldots$.$] there was$ a move towards an economics basis [for the subject].'

He added that this influence meant that accounting curricula in other universities beyond the LSE adopted its theoretical underpinning based on economics. Participant D concurred with this view. He noted that when he took his first position at an English 
university, he was 'part of an economics department.' He recalled that at this English institution:

'There was no separate accounting department at that time; there was no separate accounting degree. Everything was dictated by economists.’

As well as the role played by the LSE, the other main theme to emerge from our analysis of participants' comments was the influence of accounting practice on the university teaching of accounting. All of the participants emphasised the initial role played by accounting practice in their university teaching. This is, perhaps, unsurprising, since all came to academia having trained as professional accountants. For instance, participant C stated that:

'People of my age came into academic activity from professional practice. Therefore, you have to see that the background that we entered academic work from was really one of practice. We learned accounting with an orientation towards practice and not theory. We used books [...] which were really 'howto-do-it' texts.' 
Participant A agreed with this view commenting that there was consequently probably a lot of book-keeping in his teaching materials. Such an approach was, however, not solely the result of the background of the respondents when they started lecturing. A majority of the participants noted that this emphasis on practice and accounting techniques was expected of them. For example, participants $\mathrm{C}$ pointed out that:

'[T]he head of the technical college who was looking for a lecturer in accounting [to teach administration] approached me and asked me if I would take the job. I thought that it might be an interesting opportunity [and agreed].'

Further, our participants indicated that their emphasis on practice was due, in part, to their respect for the profession in which they all had trained. In many ways, the comments of the participants chimed with the views Baxter expressed to Walker (2005: 32) as he highlighted the influence of professional practice at the beginning of his academic career: '[...] we were overawed by the immense prestige of practice, and felt diffident about criticising it.’

\section{Influences on the teaching of accounting at Scottish universities}

Our analysis of the participants' comments highlighted that the influence of accounting practice on the teaching of accounting at Scottish universities was also strong. 
Participant D was clear about this point when he noted that his early teaching at a Scottish university focused on the techniques and intricacies of technical accounting. He pointed out that his initial teaching was to students who aspired to become practitioners in accounting, and that he was required to, at least, meet their expectations in this sense. This demand for practice-orientated material from their students suited the new staff that had been appointed to lecture in accounting. For example, although participant $\mathrm{F}$ had two undergraduate degrees, neither was in accounting; therefore, when lecturing in accounting he had to rely on what he had learned as part of his professional training. The background of this accounting educator in Scotland was fairly typical among our study participants; in fact, it is also similar to the profiles identified by Mumford (2007) among the prominent twentieth-century accounting educators ${ }^{19}$ that he consulted as part of his investigation.

Two of our participants highlighted their view that the influence of practice on the teaching of accounting at universities was stronger in Scotland than in England. For instance, participant D said that:

'[...] there was very little [theoretical content to accounting education at Scottish universities] actually. Most of the departments of accounting in Scotland at the time were very different from [their counterparts in] England where if you went to university, you did accounting usually in association with economics. In 
Scotland, you either did it with business studies or with law. There was no accounting degree; you did a [Bachelor of Commerce] or a [Bachelor of Laws]. It was largely [part-timers who taught you]. There were relatively few full-time staff.'

Participant D continued that university-level accounting education was very different in Scotland and England. He put this down to the:

'[...] Scottish tradition of [...] universities having part-time professors (who worked in practice), no full-time staff and the academic community just [contributing] as a way to beef-up chartered accountancy qualifications in the third year of a five-year apprenticeship.'

He argued that:

'[...] these part-time professors of accounting from practice treated the university as a client. That's how the university was billed. They never asked for any resources, they were just simply providing a service. If they needed additional [support] they went to their own staff [in the accounting firm] and these people did the tutoring or whatever.' 
Participant A reinforced this perspective when he stated that:

'Scotland was a bit different because the Scottish Institute had a different attitude to the English Institute. There were part-time Scottish professors who were basically practitioners doing a very good job - but not really starting off proper academic accounting.’

Participant A pointed out that the influence of the profession continued in Scotland's universities even when the first full-time professors of accounting began to be appointed. For instance, he noted that when he was interviewed for his first, full-time chair in Scotland,

'[...] there was a representative of the Scottish Institute [on his appointment committee to ensure that] he had a professional qualification and [was] sympathetic to the profession.'

He also pointed out that the part-time professor (from practice) whom he succeeded (when this Scottish university established a full-time Chair in Accounting) remained on 
the university staff after the participant's appointment. The part-time professor continued to teach a number of classes, and to advise senior staff in the institution.

The prominent role played by practitioners in accounting education within Scottish universities was not positively viewed by all of the respondents. For instance, participant $\mathrm{B}$ argued that it impeded the theoretical development of the subject in Scotland. He said:

'I have to say that I have a huge admiration for Scotland but I don't think that the practitioner [ethos] there advanced the theory much. It did advance the respectability of accounting; they taught the techniques well [and] had admirable ethical values [...] but they didn't advance the theory of the subject. At least economics at the LSE gave [the subject] a theoretical bite [in England].’

In participant C's opinion, economics was much less dominant in university accounting curricula in Scotland. He believed that the study of accounting there was much more closely aligned with the discipline of law. Participant F concurred noting that he had a first degree in law, along with many of those who trained to be professional accountants in the late 1960s. It was perhaps predictable, therefore, that he drew on this legal background when he first started to teach accounting at a Scottish university. 
Participant C suggested that such influences initially gave rise to a different approach to the university teaching of accounting in Scotland:

'Accounting piggy-backed on [the back of] law. Given that lawyers had always been professionally orientated, and hadn’t gotten a theoretical grounding in economics, you found, I think, a somewhat different, more practice-orientated development within [the teaching of accounting] in Scotland in the early years. It was only later $[\ldots]$ that an economics bias [was introduced].'

This influence of law and of the Scottish legal profession in the early years of accounting education at Scottish universities was seen to offer some benefits. For instance, the participants noted that, in some sense, the academy and the profession in Scotland were more inclined to work towards a shared vision of how to improve accounting education at the university level. By contrast, in England, the ICAEW was seen as resisting investment in graduate salaries and failing to participate in discussions with universities about how the academic discipline of accounting should develop (see also Evans, 2010; Parker, 1997; Zeff, 1997). Participant A recalled the ICAEW's Parker Report (1961) in which any contribution that universities might make towards the education of professional accountants was entirely disregarded. He recalled that 'the [ICAEW] was very against the universities and the academics' at that time. 


\section{Influence of US academics on the teaching of accounting in UK universities}

Our study sought to explore the participants' perceptions about the influence of US academics and their institutions on the teaching of accounting in universities throughout the UK. ${ }^{20}$ A number of points emerged from this part of the discussions: the influence through visits of academics between the US and UK; the influence via writings and scholarship; and the influence deriving from the control of what was published in academic journals.

It was clear from their reflections that the participants had been influenced in their thinking both by visits of academics from (as well as, more rarely, their own visits to) different parts of the world - specifically North America and Australia (see also Persson and Napier, 2014). For example, participant E felt underprepared through his Bachelor of Commerce degree for his initial teaching and so he went to North America to complete a master's degree, which he thoroughly enjoyed. However, such foreign visits by academics were quite uncommon in the 1960s and 1970s. This was largely because of the relatively high cost of travel and the small budgets available to accounting departments in UK universities. Thus, the participants who raised this issue mainly concentrated on visits by US academics, often as invited speakers at UK conferences. 
The spread of US ideas via other avenues was emphasised by more of the participants, although views of the exact timing of when this growth in the influence of ideas from the US occurred, varied among the participants. In the context of US academic influence on what was taught by accounting staff in universities in the UK, participant $\mathrm{C}$ argued that the impact in the 1960s was minimal; instead, he recalled that the early 1970s were when ideas from the USA were clearly affecting his colleagues' teaching syllabi and research. He noted of US ideas, that:

'I don't think that they impacted immediately on accounting. They came [to accounting] via financial management, [which was more of] a branch of economics. You got the big economics names such as [...] Modigliani and Miller who made a big impact [...]. By the time you get to the mid-1970s, because of the influence of the economists, we are looking to America as the most important source of academic work.’

The widespread influence of the US was even later according to the recollections of participant A. He had visiting positions in the 1960s and 1980s in Australia ${ }^{21}$ and noted that in the 1980s he was struck by the desire of young Australian academics to be published in important US journals. He reflected that: 
'[...] they believed that there were these people in Chicago mainly [...] [who] were the great men; they would tell you what to do and how to do it [...] and [if you] followed [their approach] you'd get into the American journals ${ }^{22}$.

He recalled how young Australian academics had obtained PhDs from US institutions such as the University of Chicago in the late 1960s and started to publish in US journals at that time ${ }^{23}$. This had encouraged other Australian academics to consider sending articles to US journals. By the time that he visited Australia in the early 1980s, this emphasis on publishing in US academic journals was quite pronounced. His second visit to Australia affected his own actions when he returned to the UK: he admitted to concentrating less on the writing of books about accounting and instead of starting to send off articles for journal publication.

However, the influence of the US was wider than through its academic journals: as Professor David Flint from the University of Glasgow noted when interviewed for Walker (2005), US textbooks in financial accounting, managerial accounting and auditing were relied upon by university teachers when UK accounting degrees were in their infancy . Some of the participants in the current investigation put forward the same opinion; for instance, participant $\mathrm{D}$ noted the impact on his teaching when he discovered US textbooks: 
'[...] I joined the AAA [American Accounting Association] [...] and [discovered] their text[s] [...]. Suddenly a whole world opened up [...]. That got me into American literature; once you started reading an American textbook with American references, then that referred you to [other books and articles].'

Participant $\mathrm{C}$ agreed with this view about the importance of textbooks by US academics in informing accounting teaching in universities in the UK; he also indicated that these textbooks encouraged his academic peers to read what was being published in US journals.

'The Americans were ahead of us in developing [books and teaching materials which referenced US journal articles] so we tended to move towards the American literature.’

Some of the discussion about US academic influences on accounting education focused on consequent changes to what was taught in UK universities. In this respect, the responses of our participants could be summarised by the insights of Reiter and Williams (2004: 355); they highlighted the emergence of 'economic man' within business education: 'a self-interested and shallow character'. Participant B supported this conclusion noting the growing influence within accounting education from the 
1970s of simplistic assumptions about individual economic actors who wish only to cut costs and increase revenues. Similarly, participant C expressed regret about this changing situation:

'All of the economist, finance-driven perspectives of the 1970s and 1980s with the heavy American dominance has driven us to the perception of the objective of accounting which has misinterpreted what it should be [...]. It should be [based on] how do we measure performance to achieve what society needs.'

Participant B also voiced some criticisms:

'a lot of the [economic] thinking about accounting is the really naïve-efficient markets-perfect markets in equilibrium assumptions that accountants adopt [...]. I think the underlying perfect market assumptions are based on the very simple economics that they teach people in American Master of Business Administration (MBA) courses. A lot of American academic accountants have done MBA courses, usually in Chicago, which are quite heavily biased in the economics they teach. They teach a very simple form of free market economics and just one model; you know, it isn't modern economics in the round.' 
Participant E also regretted the influence of such thinking in the current context:

'the enormous move in academic accounting in this country-even more in the States-towards [...] empirical numbers, and econometrics is [worrying], and if you can't test it in terms of the econometrics, it's not worth having. Well, for that, you need a lot of very simplifying assumptions [which are often unrealistic].’

The extant literature shows that the primacy accorded to shareholders in contemporary mainstream finance and accounting owes much to the influential work of Jensen and Meckling (1976) and Fama (1980) (see Collison et al., 2014). One key concern of Jensen and Meckling (1976) was that discretionary management objectives were not congruent with the financial interests of shareholders and that financial markets had a disciplinary function (Aglietta and Reberioux, 2005; Ireland, 2008). Participant D recalled very clearly the increasing influence of capital markets research by the late 1960s and early 1970s within the university teaching of accounting in the UK. He noted the particular significance of Jensen and Meckling's (1976) US work on agency, and the capital market studies, which referred to it. In his mind, there were clear links with the growing emphasis on MSW that occurred in education, and in society more widely, during this period. 
Given the prominent role played by the LSE and its economics-informed perspective in the emerging accounting discipline at UK universities, this widespread acceptance of developments from economic thinking, even though deriving from the US, is perhaps to be expected. However, the speed with which it changed what was taught at UK universities surprised participants in the study. Nowhere was this change more noticeable, according to the participants, than in the narrowing of the goals thought to underpin the operations of firms. Participant $\mathrm{C}$ had published on, and taught about, a range of different goals for the firm at the start of his career but found that textbooks began to focus (almost exclusively) on the MSW notion in the 1970s. ${ }^{24}$

'It was certainly changing by the 1970s. We [...] moved [from] a situation where there was a concept of maximising for other people to [MSW].'

Participant C maintained that:

'The majority of the academic work [in the US] is very much orientated towards the concept of shareholder [wealth] maximisation. You find that that runs through the financial management textbooks [...] it was present from the mid1970s onwards.' 
Indeed, participant A recalled, from his early days in the academy, the negative reception to some fundamental ideas of visiting US economist, Ezra Solomon. Solomon discussed MSW as the primary goal of the firm when he delivered a guest lecture to London and Manchester Universities’ business staff:

'He quite explicitly [...] in the first few sentences had said [...] in what follows I'm going to assume maximisation of shareholder wealth and so on and [...] from that I will build [...] etc., etc. and the roof came down, you know. Everybody was screaming, you can't do that, that's not [appropriate] - and the poor chap was absolutely astonished [...]. [He] never got much further with the paper.’

\section{Concluding comments}

A number of conclusions emerge from the narratives of the participants in this study. Some of these conclusions echo findings already documented in the literature: the key role played by the LSE, notably through the second wave of accounting professoriate, in shaping the development of university accounting education in the UK; the different influences on, and paths taken by, the academic discipline of accounting in Scotland and England; and the influence of the US on the teaching of accounting in UK universities. However, even here the participants were able to add subtle first-hand insights on how 
these forces operated in practice and affected the discipline that they were involved in teaching as well as researching. For instance, some of the participants' narratives referred to the role played by the 'LSE Triumvirate' — especially Solomons and Edeyon appointment committees for chairs of accounting at universities in Scotland and England. The impact of these LSE professors in shaping accounting through their roles as external examiners for undergraduate courses or as advisers for the launch of new accounting degree programmes was also noted.

An analysis of the narratives also allows several new conclusions to emerge. This was especially true for the participants' observations about US academic influences on university accounting education in the UK; for instance, the growth of agency theory and the rise to prominence of MSW in the teaching (and researching) of accounting was striking. One of the key insights of the participants in this paper is that MSW's emergence as the dominant goal of business seems to have increased in the late 1970s and early 1980s due, in part, to the influence of US (mainly financial management) textbooks. In addition, the clear role of (an initially small number of) journals in spreading ideas and research techniques, which relied upon a narrow objective for managers to follow, is apparent. Certainly, participants noted a distinct and persistent change from an earlier time. In particular, when a guest lecture by American, Ezra Solomon, to academics from across the UK caused consternation by assuming that businesses existed in order to maximise shareholders' wealth. 
More work is needed on the extent to which this influence of US academics endures, specifically in terms of the detail about how their ideas came to dominate what was taught, and researched, in university accounting departments. In addition, further research on the expansion of accounting as a distinctive degree offering within UK universities would aid our understanding of the current structure of accounting programmes and accounting academia within higher education. Documenting the experiences of the women in the third wave of accounting professors would also provide valuable insights to the shape of the academic discipline. Clearly, the insights from this sample of the second-wave of UK accounting professors suggest a number of research avenues that can be pursued to build upon the findings reported. 


\section{References}

Aglietta M and Reberioux A (2005) Corporate Governance Adrift. A Critique of Shareholder Value. Cheltenham: Edward Elgar.

Annisette M and Kirkham LM (2007) The advantages of separateness explaining the unusual profession-university link in English Chartered Accountancy. Critical Perspectives on Accounting 18(1): 1-30.

Badua FA, Previts GJ and Vasarhelyi MA (2011) Tracing the development of accounting thought by analysing content, communication, and quality in accounting research over time. The Accounting Historians Journal 38(1): 31-56.

Baker CR (2011) A genealogical history of positivist and critical accounting research. Accounting History 16(2): 207-221.

Baskerville RF (1999) The Telling Power of CCA - A New Zealand Oral History. The Accounting Historians Journal 26(1): 1-26.

Baxter WT (1988) Accounting research - Academic trends versus practical needs. Edinburgh: ICAS. 
Burrows GH (1999) A Response to Lou Goldberg's Concerns about Oral History. Accounting History 4(1): 99-106.

Carnegie GD and Napier C (1996) Critical and interpretive histories: insights into accounting's present and future through its past. Accounting, Auditing \& Accountability Journal 9(3): 7-39.

Carnegie GD and Williams BG (2001) The first professors of accounting in Australia. Accounting History 6(1): 103-115.

Clarke P (2005) The story of Bernard F. Shields: The first professor of accountancy in the UK. Accounting History 10(2): 103-123.

Collins M and Bloom R (1991) The role of oral history in accounting. Accounting, Auditing \& Accountability Journal 4(4): 23-31.

Collison D, Cross S, Ferguson J, Power D \& Stevenson L (2014) Financialization and company law: A study of the UK Company Law Review. Critical Perspectives on Accounting 25(1): 5-16. 
Dev S (1980) Accounting and the LSE tradition: An inaugural lecture. London: The London School of Economics and Political Science.

Devine T (2013) The sixties in Scotland: A historical context. In: Bell E and Gunn L (eds) The Scottish Sixties: Reading, Rebellion, Revolution. Amsterdam: Rodopi.

Duff A and Ferguson J (2011a) The Construction of disability by accounting institutions: Experiences of disabled accountants. Critical Perspectives On Accounting 22(4): 351-364.

Duff A and Ferguson J (2011b) Disability and the professional accountant insights from oral histories. Accounting, Auditing \& Accountability Journal 5(1): 71-101.

Evans E (2009) Monitoring accounting education in higher education institutions by the professional accounting bodies in Australia 1944-1988. In: Baxter J and Poullaos C (eds) Practices, Profession and Pedagogy in Accounting. Essays in Honour of Bill Birkett. Sydney: Sydney University Press, pp.398-428. 
Evans E (2010) Jurisdictional disputes in accounting: education or training. In: Evans E, Burritt R and Guthrie J (eds) Accounting Education at a Crossroad in 2010. Adelaide: The Institute of Chartered Accountants incorporated in Australia and the University of South Australia, pp.80-89.

Evans E (2014) The interface between academic education and professional training in accounting. In: Wilson RMS (ed) The Routledge Companion to Accounting Education. Oxon: Routledge, pp.632-651.

Fama EF (1980) Banking in the theory of finance. Journal of Monetary Economics 6: 39-57.

Fearfull A and Kamenou N (2006) How do you account for it?: A critical exploration of career opportunities for and experiences of ethnic minority women. Critical Perspectives on Accounting 17(7): 883-901.

Fleischman R and Radcliffe, V (2005) The roaring nineties: Accounting history comes of age. The Accounting Historians Journal 32(1): 61-109. 
Gammie E and Kirkham L (2008) Breaking the link with a university education in the creation of a chartered accountant: The ICAS story. British Accounting Review 40(4): 356-375.

Geddes SB (1995) The development of accountancy education, training and research in England: A study of the relationships between professional education and training, academic education and research, and professional practice in English Chartered Accountancy. PhD thesis, University of Manchester, UK.

Hammond T (2002) A White-Collar Profession: African American Certified Public Accountants since 1921. Chapel Hill and London: The University of North Carolina Press.

Hammond T and Sikka P (1996) Radicalising accounting history: the potential of oral history. Accounting, Auditing \& Accountability Journal 9(3): 79-97.

Haynes, K. (2010). Other lives in accounting: critical reflections on oral history methodology in action. Critical Perspectives on Accounting, 21(3), 221-231

Haynes K (2008a) (Re)figuring accounting and maternal bodies: The gendered 
embodiment of accounting professionals. Accounting, Organizations and Society 33(4): 328-48.

Haynes K (2008b) Transforming identities: accounting professionals and the transition to motherhood. Critical Perspectives on Accounting 19(5): 620 - 642.

Heck JT and Jensen RE (2007) An analysis of the evolution of research contributions by The Accounting Review, 1926-2005. The Accounting Historians Journal 34(2): 109141.

Ireland P (2008) Financialization and Corporate Governance. Corporate Governance and Globalisation Colloquium. Available at SSRN: https://ssrn.com/abstract=2068478

Jensen MC and Meckling WH (1976) Theory of the firm: Managerial behaviour, agency costs and ownership structure. Journal of Financial Economics 3(4): 305-360.

King R and Davidson I (2009) University accounting programs and professional accountancy training: Can UK pragmatism inform the Australian debate? Australian Accounting Review 19(3): 261-273. 
Kyriacou O (2000) Gender, ethnicity, and professional membership: The case of the accounting profession. PhD Thesis, University of East London, UK.

ICAEW (1961) Report of the Committee on Education and Training ('The Parker Committee Report'). London: ICAEW.

Lee T (1995) Shaping the US academic accounting research profession: The American Accounting Association and the social construction of a professional elite. Critical Perspectives on Accounting 6(3): 241-261.

London School of Economics (2007) Professor Harold Edey, 1913-2007. Available at: http://www.lse.ac.uk/accounting/news/edey_tribute.aspx (accessed 16 Nov 2015).

Long RG, Bowers WP, Barnett T and White MC (1998) Research productivity of graduates in management: effects of academic origin and academic affiliation. The Academy of Management Journal 41(6): 704-714.

Matthews D (2000) Oral history, accounting history and an interview with Sir John Grenside. Accounting, Business and Financial History 10(1): 57-83. 
McNicholas P, Humphries M and Gallhofer S (2004) Maintaining the empire: Maori women's experiences in the accounting profession. Critical Perspectives on Accounting 15(1): 57-93.

Mumford MJ (1991) Chartered accountants as business managers: An oral history perspective. Accounting, Business and Financial History 1(2): 123-40.

Mumford MJ (2007) Their Own Accounts: Views of Prominent $20^{\text {th }}$ Century Accountants. Edinburgh: ICAS.

Napier CJ (1996a) Accounting and the absence of a business economics tradition in the UK. European Accounting Review 5(3): 449-481.

Napier CJ (1996b) Academic disdain? Economists and accounting in Britain, 18501950. Accounting, Business and Financial History 6(3): 427-450.

Napier CJ (2011) Accounting at the London School of Economics: Opportunity lost? Accounting History 16(2): 185-205. 
Parker LD (1994) Impressions of a scholarly gentleman: Professor Louis Goldberg. The Accounting Historians Journal 21(2): 1-40.

Parker LD (1997) Informing historical research in accounting and management: traditions, philosophies, and opportunities. The Accounting Historians Journal 24(2): 111-49.

Parker RH (1978) British men of account. Abacus 14(1): 53-65.

Parker RH (1995) David Solomons and British accounting. Accounting and Business Research 25(100): 311-314.

Parker RH (1997) Flickering at the margin of existence: the Association of University Teachers of Accounting, 1960-1971. British Accounting Review 29 (Special issue): 4161.

Parker RH, Zeff SA and Anderson M (2012) Major Contributors to the British Accountancy Profession: A Biographical Sourcebook. Edinburgh: ICAS. 
Perkin HJ (1969) New Universities in the United Kingdom. Case Studies on Innovation in Higher Education. Paris: Organisation for Economic Cooperation and Development, Centre for Educational Research and Innovation.

Perks R (1995) Oral History: Talking about the Past. London: The Historical Association.

Perks R and Thomson A (1998) The Oral History Reader. London: Routledge.

Perks R (2004) Financial Accounting: Understanding and Practice (2 ${ }^{\text {nd }}$ Edition). London: McGraw-Hill.

Persson ME and Napier CJ, (2014) The Australian accounting academic in the 1950s: R.J. Chambers and networks of accounting research. Meditari Accountancy Research. 22(1): $54-76$.

Poullaos C (2010) The profession/academy relationship and entry to professional programs. In: Evans E, Burritt R and Guthrie J (eds) Accounting Education at a 
Crossroad in 2010. Adelaide: The Institute of Chartered Accountants incorporated in Australia and the University of South Australia, pp. 63-71.

Reinharz S (1992) Feminist methods in social research. New York: Oxford University Press.

Reiter SA and Williams PF (2002) The structure and progressivity of accounting research: The crisis in the academy revisited. Accounting, Organizations and Society 27(6): 575-607.

Reiter SA and Williams PF (2004) The philosophy and rhetoric of auditor independence concepts. Business Ethics Quarterly 14(3): 355-376.

Rodgers JL and Williams PF (1996) Patterns of research productivity and knowledge creation at The Accounting Review: 1967-1993. The Accounting Historians Journal 23(1): 51-88.

Shackleton K (1992) The evolution of education policy within the Institute of Chartered Accountants of Scotland. In: Anyane-Ntow K (ed) International Handbook of Accounting Education and Certification. Oxford: Pergamon Press, pp.417-444. 
Sian S (2006) Inclusion, exclusion and control: The case of the Kenyan accounting professionalisation project. Accounting, Organizations and Society. 31(3): 295-322.

Solomons D (1961) The Report on Education and Training: Failure of a Mission Accountancy. July: 407-412.

Spacek L (1990) The Growth of Arthur Andersen and Co. 1928-1973. An Oral History. New York: Garland.

Tricker RI (1975) Research in Accounting - A Strategy for Further Work. Brooklyn, NY: Social Science Research Council.

van Wyhe G (2007) A history of US higher education in accounting, Part 1: Situating accounting within the academy. Issues in Accounting Education 22(2): 165-181.

Walker SP (1988) The Society of Accountants in Edinburgh 1954-1914: A study of recruitment to a new profession. New York: Garland. 
Walker SP (2005) Giving an Account: Life Histories of Four Eminent CAs. Edinburgh: ICAS.

Yow VR (2005) Recording Oral History: A Guide for the Humanities and Social Sciences. Plymouth: AltaMira Press.

Zeff SA (1997) The early years of the Association of University Teachers of Accounting: 1947-1959. British Accounting Review 29 (Special issue): 3-39. 
Table 1 - Some biographical details of the participants in the study

\begin{tabular}{|l|c|c|c|c|c|}
\hline Participant & Attended LSE & $\begin{array}{r}\text { Professional } \\
\text { Accounting }\end{array}$ & $\begin{array}{c}\text { First full-time } \\
\text { academic }\end{array}$ & Gender & Main location \\
& & Qualification & position & & \\
\hline A & NO* & YES & 1966 & Male & England \\
\hline B & YES & YES & 1967 & Male & England \\
\hline C & YES & YES & 1967 & Male & Scotland \\
\hline D & YES & YES & 1972 & Male & Scotland \\
\hline E & NO & YES & 1967 & Male & England \\
\hline F & NO & YES & 1968 & Male & Scotland \\
\hline
\end{tabular}

* $\quad$ Worked at LSE 


\section{Endnotes}

${ }^{1}$ Bernard Shields was appointed to 'the earliest full time Chair in a UK university with accountancy or accounting in its title’ (Zeff, 1997: 6), which was established at University College Galway [in Ireland] in 1914. At that time Ireland was a part of the UK. The first Professor of Accounting appointed on the British Isles was a part-time position at the University of Birmingham in 1902 (Zeff, 1997: 4). In Scotland the first Professor of Accounting was also a part-time position, established in 1919 at the University of Edinburgh (Zeff, 1997: 5).

${ }^{2}$ Walker (2005) edited this ICAS sponsored publication of interviews with four highly influential Scottish accountants: Professor William Baxter, Professor David Flint, Sir Ian Morrow and Sir John Calman Shaw.

3 The participants were guaranteed anonymity when they agreed to participate in this research so no names are supplied in the analysis. Nevertheless, the backgrounds of the individuals are sketched out in the method section so that their wealth of experience is apparent to the reader.

${ }^{4}$ One of our participants, however, did start teaching accounting in the 1950s but this was at a technical college - before he moved to the university sector.

${ }^{5}$ In some form at least, accounting has had a presence in UK universities since the Middle Ages: Dev (1980: 1) noted that '[a]s a subject taught in the [UK] Universities [...] [accounting] was well established by the end of the thirteenth century [...] at Oxford'.

${ }^{6}$ In 1961 there existed twenty-two universities and four university colleges in the United Kingdom; by 1969, an additional twenty-four universities and a university college had been created (Perkin, 1969). Devine (2013: 24) recalls the ample student grants and absence of fees during his university studies of the 1960s. He further invokes the excitement generated by Harold Wilson's vision of introducing the 'white heat of the technological revolution’ (Devine, 2013: 40) following his 1964 election victory. 
${ }^{7}$ However Carnegie and Napier (1996: 12) date the 1950s as 'a crucial period when academic teaching and research in accounting was expanding rapidly'.

${ }^{8}$ Although Napier (1996b: 452) states that 'theoretically oriented writings on accounting matters began to emerge in Britain with The Accountant in 1874'.

${ }^{9}$ This organisation was known as the British Accounting Association (BAA) for much of its history.

${ }^{10}$ Five of our participants had received one of these awards.

${ }^{11}$ It is worth highlighting that the total population of academics with comparable and contemporaneous experience is, in itself, small.

${ }^{12}$ It is relatively rare, within a discipline, to be able to speak with those who were heavily involved at the time when their subject area became established as the basis of a degree programme at the university level. Because of the relatively recent widespread introduction of accountancy degree programmes in universities in the 1960s and 1970s this opportunity existed for accounting. Such a possibility was another motivation behind our decision to involve these academics in order to document their insights and reflections for current and future generations.

${ }^{13}$ All of our participants did some part-time tutoring at various colleges and/or universities before leaving the accounting profession and becoming a full-time academics. In addition, two of the academics (A and E) spent a number of years abroad-either studying, working as accountants or teaching—before returning to a full-time lecturing post in the UK. The dates referred to in Table 1 related to the years when these academics took up their first full-time academic post in the UK.

${ }^{14}$ All of the participants were in good health when their oral histories were collected and certainly expressed no difficulty in remembering events from the start of their academic careers in the late 1960s and early 1970s. 
${ }^{15}$ The only possible exception to this generalisation was participant $\mathrm{F}$ who lectured mainly in finance throughout his academic career. Even here, participant F conceded that 'he could see that William Baxter and the LSE was [sic] influential - but it did not affect [him].'

${ }^{16}$ Carnegie and Williams (2001: 106; see also Clarke, 2005) however note that 'the earliest full-time Chair with accountancy or accounting in the title was held by Bernard F. Shields who was appointed as Professor of Commerce and Accountancy at University College Galway in 1914’.

${ }^{17}$ See also LSE (2007)

${ }^{18}$ Between 1965 and 1992 polytechnics were vocationally focussed institutions of higher education in the UK.

${ }^{19}$ Of Mumford's (2007) twelve academic profiles, three had studied economics, two held Bachelor of Commerce degrees, and six had no undergraduate degree at all. The remaining individual had studied Classics as an undergraduate. See also Parker (1978).

${ }^{20}$ An explanation for the influence of the US on accounting practice and theory is noted by Mumford (2007: 4) in his discussion of the 'historical context of accounting for large-scale enterprises'. He highlights that '[b]ecause of the accidents of history, many accounting developments took place in the US earlier than they did in the UK.' (Mumford, 2007: 6).

${ }^{21}$ Professor David Flint (Walker, 2005: 91) also noted the early influence of Australian academics on the developing UK discipline; whilst a reciprocal influence is evident when Parker, Zeff and Anderson (2012: 8) note 'Beginning in the 1970s, the outlook of British accounting academics [also] became much more international'.

${ }^{22}$ Academic D recalled that when Baxter initially established the Journal of Accounting Research, in partnership with the University of Chicago, a clear policy was that half of each edition's published articles should come from academics in the US, and half from academics in the UK. 
${ }^{23}$ Baker (2011) explores the profound influence of 1960s and 1970s doctoral students on subsequent critical and positive accounting research.

${ }^{24}$ However respondent B believed that MSW was more accurately an ‘Anglo-American’ term:

'I'm not so keen on this idea that maximising shareholder wealth is [...] from the US; you know, as an economist, Alfred Marshall wrote all this [in the UK in the late nineteenth century], after all, long before the Americans thought of it'. 